\title{
コロニー形成時間の異なる細菌群集の性質の比較
}

\author{
森川和子*・大 塚 真 理** \\ 東京農工大学一般教育部 \\ ₹ 183 府中市幸町 3-5-8
}

(受付 1991 年 3 月 15 日一受理 1991 年 8 月 27 日)

\section{Characteristics of bacterial communities having different colony forming time on agar plates}

\author{
Kazuko Morikawa and Mari Otsuka \\ Laboratory of Biology, Tokyo University of Agriculture and Technology \\ 3-5-8 Saiwai-cho, Fuchu, Tokyo 183, Japan
}

\begin{abstract}
Summary : Bacterial communities in epilithon on the river bed were examined at the Tamagawa River by a plate count method. Colonies developed on 1/2 PYG agar plates were classified into four groups according to the colony forming time. Incubation periods which were needed for the colony formation were between 0 and 48 hours for group A, 24 and 72 hours for group B, 120 and 168 hours for group C, and 288 and 336 hours for group D. Generic compositions and diversity indexes of the four groups were similar each other. On the other hand, positive reaction against morphological and physiological characterization (specific total activity) of these groups were quite different each other. Group A, which contains the organisms having the fastest colony forming time, had high specific total activity. On the other hand, group D, which is constituted with the bacteria having the slowest colony forming time, had lowest specific total activity. Most bacterial strains of the group A grew rapidly on the $1 / 2$ PYG agar medium, too. However, the group D included organisms which grew both rapidly and slowly on this medium. Based on these results, the colony formation of the bacteria seemed to prescribe largely by the physiological conditions of the cells at the time when cells were placed on the agar plates.
\end{abstract}

\section{諸言}

自然界に生息している細菌群集の存在状態は，実に 多様である。今まさに分裂しょうとしているるの,ちょ らど分裂が終わった状態にあるもの，休眠状態にある ものなど, 又生理活性の高いものもあるし，非常に低 いものもある。この様に多様な存在状態にある自然界 の細菌群集の動態を解析する 1 つの手段として, 用い る培養基組成や培養温度など検討されるべき問題はあ るものの, 平板培養法は有用な情報を与えてくれる。平

* Corresponding author

** 現住所 德山曹達株式会社つくば研究所 つくば市和台 40
板上に生じたコロニーを経時的に計数することによっ て，そこに生息している細菌群集を構成している個々 の細菌の存在状態の一側面を把握することができる。 自然環境に生息している細菌群集を平板法で計数す る場合，平板上のコロニーは同時に肉眼で識別される 大きさになるわけではない。服部1) は, 経時的に平板上 に形成されるコロニーを計数することによって，コロ ニ一形成は一次反応式に従って起こることを明らかに した。これ平板上にコロニーが形成される確率は, 平 板に置かれた細菌の生理状態によって決まるとしてい る。清水等》 は, コロニ一形成の過程を追って細菌群集 を分離同定した結果, 分離に用いる培養基の組成に よってコロニーが出現する時間に差があると報告し 
た。そして、コロニー形成が確率によって決まるとし ても，そ机は培養条件に上って左右されるような相対 的なものであろらと報告している。

本報では, 自然環境に生息している細菌群集を平板 法を用いて計数する場合，コロニー形成時間が異なる 細菌株間にどのような生理的性質の違いがあるか，ま たそれは自然界に抢ける細菌群集のどのような側面を 反映しているかについて明らかにしょうとしたもので ある。多摩川に沶いて河床の石面付着層を対象に, 平 板上に生じたコロニーをその形成時間に基づいて4つ のグループにわけて釣菌し，各グループを構成する細 菌株の属構成ならびに生理的な性質について検討した 結果を報告する。

\section{材料および方法}

石面付着層の採取：1986 年 4 月 9 日, 多摩川の是政 橋下流右岸に打いて, 水深 $20 \mathrm{~cm}$ の河床の石を静かに 取り出し, 石の上面の付着層 $5 \times 5 \mathrm{~cm}^{2}$ を採取した。こ 孔を河川水 $200 \mathrm{ml}$ に懸濁して現場の水温と同じ温度 で実験室に持ち帰り, 120 秒間超音波処理 (Nihon Seiki $28 \mathrm{kHz}$ ) したものを付着層サンプルとした。採取
方法の詳細は前報に述べた ${ }^{4)}$ ここの付着層の付着物乾 量は $11.82 \mathrm{mg} \cdot \mathrm{cm}^{-2}$, クロロフィル量は $16.7 \mu \mathrm{g} \cdot \mathrm{cm}^{-2}$ であった。また，付着層採取時の水温は $16.5^{\circ} \mathrm{C}, \mathrm{pH}$ 8.40, DO 9.46 ppm (129.3\%), DOC $4.93 \mathrm{mgC} \cdot 1^{-1}$ で あった。

細菌の計数：付着層サンプルを滅菌水道水を用いて $10^{-4}$ に希橎後, $1 / 2 \mathrm{PYG}$ 平板 (ポリペプトン $1 \mathrm{~g}$, イー

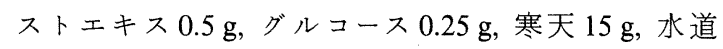
水 $1,000 \mathrm{ml}, \mathrm{pH}$ 7.0) 50 枚に各 $0.1 \mathrm{ml}$ を平面塗抹した。 これを $20^{\circ} \mathrm{C} て ゙$ 培養後, 経時的に生じたコロニ一数を 計数した。Fig. 1 に 50 枚のらち代表的な 1 枚の平板か ら党たコロニー形成曲線を示した。このコロニー形成 曲線は 2-4成分からなっているとも考学られるが，こ れを 1 成分と仮定して，石栗等 2 とよるコロニ一形成 時間 $(t)$ と,コ口二-数 $(N)$ の関係式 $\operatorname{In}\left(N_{0}-N\right)=$ In $N_{0}-\lambda(t-t r)$ に基づいて最初の 7 点をもとに計算 した $\lambda$ の值は $0.249, \operatorname{tr}$ は 31.2 時間であった。なお, 本 サンプルのアクリジンオレンジ染色による全菌数は, $1.6 \times 10^{9} \mathrm{cell} \cdot \mathrm{cm}^{-2}, 1 / 2 \mathrm{PYG}$ 平板による生菌数は $8.8 \times 10^{7} \mathrm{cell} \bullet \mathrm{cm}^{-2}$ であった。

細菌グループの決定：予備実験の結果を考慮して, コロニー形成過程のできる限り多くの部分を代表でき

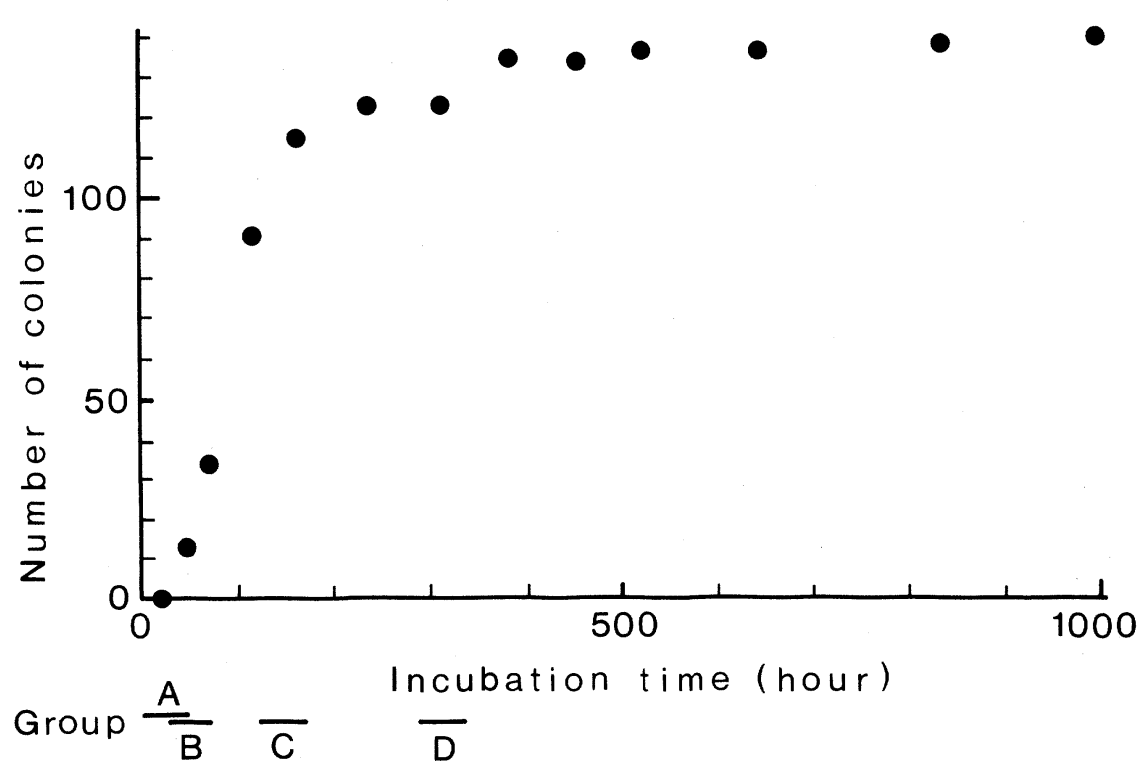

Fig. 1. Changes in the number of colonies of the river epilithon at the Tamagawa River developed on the $1 / 2$ PYG agar plates. Bars correspond to the periods of picking up the colonies from the agar plates. 
るように，培養時間を以下のように決定した。平板培 養後， 0-48 時間に生じたコロニーを計 8 枚の平板から

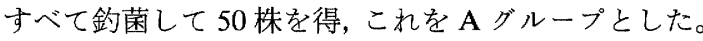
残りの 42 枚の平板に培養後 24 時間目までに生じたコ ロニ一に印をつけて除き，培養後 24-72 時間に生じた コロニーを計 2 枚の平板から 60 株釣菌して B グルー プとした。同様に 120-168 時間に生じたコロニーを計 4 枚の平板から釣菌して 51 株を得て C グループとし， 288-336 時間に平板に生じたコロニーを計 25 枚の平 板から釣菌して 50 株を得て D グループとした。各グ ループに相当するコロニー形成時間を Fig. 1 の下にし めした。釣菌したコロニーを繰り返し画線培養した結 果, A グループ 65, B グループ 61, C グループ 49, D グ ループ 38 の純粋株を継代可能な菌株として得た。

属レベルでの細菌の種類の決定：純粋分離した 213 菌株についてグラム染色，芽胞染色，コロニーの色・ 性状, 細胞の形態, 鞭毛のつきかた, 酸素要求性, 運 動性, オキシダーゼ活性, カタラーゼ活性, OF テスト (グルコース・シュークロス・ラフィノース・でんぷん・ グリセリン)，ゼラチンの液化能，リトマスミルクに対 する反応を検査した。これらの検査方法については前 報によった5)。李た，カルボキシメチルセルロース (CMC) の分解能については染谷9) に従って検査し た。これらの結果をもとにして, 細菌株の属を Bergey's Mannual of Systematic Bacteriology ${ }^{3,8,10,11)}$ 飞従って決 定した。さらに,これらの属を1つの分類単位として Shannonの多様度指数 $(\overline{\mathrm{H}})^{6)}$ 計算した。

全活性の計算：分離して諸生理学的性質を検査した 各々の菌株について，運動性の有るもの，オキシダー ゼ活性・カタラーゼ活性・ゼラチンの液化能・リトマ スミルクの反応・CMC の分解能が $(+)$ であるもの, グルコース・シュークロス・ラフィノース・でんぷん・ グリセリンの OF テストで $\mathrm{pH}$ 変化を示したもの, OF テストに执いて糖をいれていないブランクでアルカリ 性を示したものの計 12 項目について (+) の項目数 の合計を各々の細菌株の全活性 (Specific total activity) とした。

増殖パターンの決定：純粋分離した菌株をサンプル 採取後 50 日目に $1 / 2$ PYG スラントに白金耳を用いて 接種し, 接種後 2, 3, 7, 14 日目にスラント面での菌株 の増殖状態を観察した。その場合，スラント面に接種 した菌株がみ壳はじめた時期が，2 日目のものをパ ターン 1,3 日目のものをパターン 2,7 日目をパターン 3,14 日目以降をパターン 4 とした。增殖のみられな
かったものは (一)と表した。

\section{結 果}

\section{4 グループの細菌群集の属構成}

コロニー形成時間の異なる 4 グループの細菌群集の 属レベルでの細菌の種類構成は, Table 1 のと括りで あった。4つのグループ間の種類構成に顕著な違いは みられず，多様度指数 (Shannon $\overline{\mathrm{H}}$ ) も大きな差はな かった。全体として, Flavobacterium の值がやや高い注 かは優占種は認められなかった。平板から釣菌した当 初, 各グループのコロニー数は注涪同数であったが, 継 代培養して性質を検査することができた菌株数は，A グループからD グループにいくにしたがって減少し た。多摩川是政に打ける河床付着層の細菌群集の各属 は，コロニー形成時間をもとにすると，出現時期が比 較的初期に限られている属 (6 属)，コロ二ー形成に 1 週間以上要する属 (3 属) があることが明らかになっ た。しかし，どのグループにも検出された属が 4 属, 出 現時期が一定しないものが 8 属あり，これらが半数以 上を占めていた。

\section{2. 各グループの生理学的性質}

\section{2-1 高分子化合物の分解能}

Fig. 2 にゼラチンの液化能，リトマスミルクに対す る反応, 招よび CMC の分解能を示した。ゼラチン液化 の形態は様々であったがこれらを合計すると，ゼラチ ンを液化した細菌株は A グループから D グループに いくにしたがって減少した。しかし，液化がみられな くともゼラチン培地で増殖した菌株は全体の約 $90 \%$

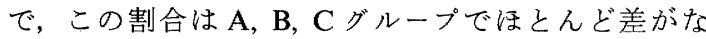
かった。リトマスミルクに対する反応をみると，ラブ 酵素を形成したり $\mathrm{pH}$ の変化がみられた菌株は全体と して少なく，菌体の増殖が確認された菌株の割合も少 なかった。CMCの分解については，分解による clear zoneを形成したものの割合がCグループにやや多 かったが，ゼラチン液化能・リトマスミルクに対する 反応と同様，D グループの細菌株の反応は弱かった。

2-2 OF テスト

5 種類の糖に関して OF テストを行った結果を Fig. 3 に示した。糖類を加光ていないブランク実験で $\mathrm{pH}$ の変化がみられた菌株の割合は, A グループから D グ ループにいくにしたがって減少した。この減少の傾向 は検査した糖類の全てについて等しく，各グループで 
Table 1. Bacterial generic compositions in the epilithon at the Tamagawa River classified into four groups according to the colony forming time on the $1 / 2$ PYG plates.

\begin{tabular}{|c|c|c|c|c|}
\hline \multirow{2}{*}{$\begin{array}{l}\text { Bacterial generic } \\
\text { composition }\end{array}$} & \multicolumn{4}{|c|}{ Incubation periods (hour) } \\
\hline & $\begin{array}{l}\text { Group } A \\
0-48\end{array}$ & $\begin{array}{l}\text { Group B } \\
24-72\end{array}$ & $\begin{array}{c}\text { Group C } \\
120-168\end{array}$ & $\begin{array}{l}\text { Group D } \\
288-336\end{array}$ \\
\hline Cytophaga & $0(0.0 \%)$ & $4(6.6 \%)$ & $2(4.1 \%)$ & $0(0.0 \%)$ \\
\hline Pseudomonas & $2(3.1)$ & $1(1.6)$ & 0 & 0 \\
\hline Pseudomonas (OX-) ${ }^{\mathrm{a}}$ & $1(1.5)$ & $6(9.8)$ & $1(2.0)$ & 0 \\
\hline Xanthomonas & 0 & $1(1.6)$ & 0 & 0 \\
\hline Flavobacterium & $8(12.3)$ & $11(18.0)$ & $4(8.2)$ & $5(13.2)$ \\
\hline Aeromonas & $4(6.2)$ & 0 & 0 & 0 \\
\hline Alcaligenes & $2(3.1)$ & 0 & $1(2.0)$ & 0 \\
\hline Enterobacteriaceae & $1(1.5)$ & $3(4.9)$ & $1(2.0)$ & 0 \\
\hline Moraxella & $3(4.6)$ & $1(1.6)$ & 0 & 0 \\
\hline Acinetobacter & $4(6.2)$ & $4(6.6)$ & $4(8.2)$ & $3(7.9)$ \\
\hline Caulobacter & $1(1.5)$ & 0 & $1(2.0)$ & $2(5.3)$ \\
\hline Micrococcus & $7(10.8)$ & $1(1.6)$ & $4(8.2)$ & $1(2.6)$ \\
\hline Staphylococcus & $2(3.1)$ & $1(1.6)$ & 0 & 0 \\
\hline Streptococcus & 0 & $2(3.3)$ & $1(2.0)$ & 0 \\
\hline Corynebacterium & $3(4.6)$ & 0 & $1(2.0)$ & $1(2.6)$ \\
\hline Arthrobacter & $3(4.6)$ & 0 & $1(2.0)$ & $1(2.6)$ \\
\hline Bacillus & $3(4.6)$ & $3(4.9)$ & $5(10.2)$ & $4(10.5)$ \\
\hline Lactobacillus & $2(3.1)$ & $2(3.3)$ & $3(6.1)$ & 0 \\
\hline Nocardia & 0 & 0 & 0 & $1(2.6)$ \\
\hline Actinomycetales & 0 & 0 & $2(4.1)$ & $4(10.5)$ \\
\hline Yeast & 0 & 0 & $6(12.2)$ & $4(10.5)$ \\
\hline not identified & $16(24.6)$ & $12(19.7)$ & $10(20.4)$ & $7(18.4)$ \\
\hline no growth & $3(4.6)$ & $9(14.8)$ & $2(4.1)$ & $5(13.2)$ \\
\hline Total number & 65 & 61 & 49 & 38 \\
\hline Shannon's index $(\overline{\mathrm{H}})$ & 2.523 & 2.249 & 2.489 & 2.129 \\
\hline
\end{tabular}

a $\mathrm{OX}-$; oxidase activity negative

一定の割合を示していた。しかし，個々の菌株の反応 は一様ではなく OFテストで反応のみられない菌株 は，ブランク実験で反応がみられなかった菌株と必ず しも一致していなかった。ブランク実験で $\mathrm{pH}$ 変化が みられなかった菌株の割合を除くと，4つのグループ に打ける好気的酸化・発酵・アルカリ変化といら OF テ ストの結果はほぼ等しかった。

\section{2-3 全活性}

Table 2 にグループ毎にそれぞれの全活性を示した 菌株数と,そのグループの全活性の平均值を示した。測 定項目全部について活性を示した菌株はなく, 最大の 值は 11 であった。4グループの平均值は A グループ
から Dグループにいくにしたがって減少し, 速くコロ ニーを生じるグループの活性は高く, 遅く生じるグ ループの活性は低かった。A グループでは11 項目に ついて (十)の值を示した菌株が 3 株あり，50\%以上 が 8 以上の值を示した。Bグループでは 11 の值を示し た菌株がやはり 3 株あったが, 50\%の菌株は 6 以上で, Cグループでは最高が9であり，3のものが最す多く 11 株 23.4\%を占め，Dグループでは，60\% 以上の菌株 が 2 以下の值であった。

\section{3. スラントにおける増殖パターン}

サンプル採取後 50 日目にスラントに接種した菌株 


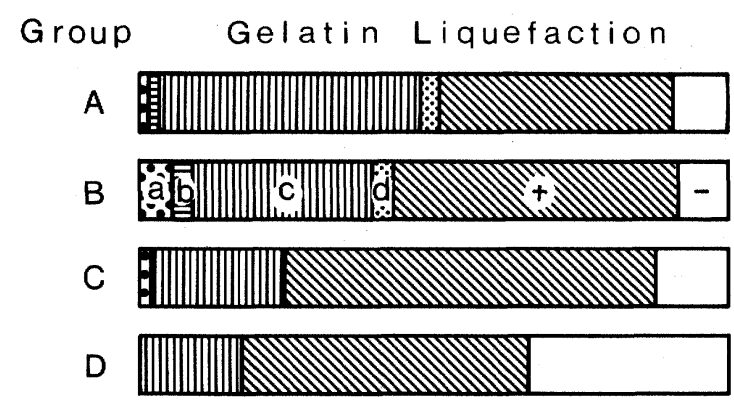

Litmus Milk

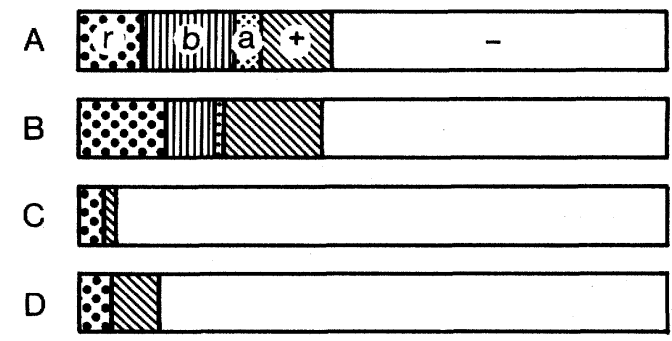

CMC Decomposition

A

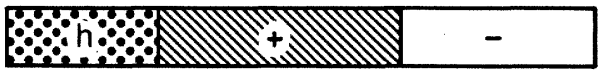

B

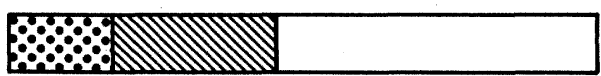

C

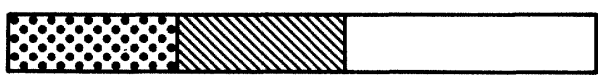

D

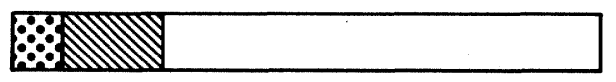

年

50

ラント上に白金耳で接種した菌体が肉眼で見えるコロ ニーを形成するまでの時間は接種量によってバラッキ が生じる。しかし，多くの場合，ここで用いた範囲内 での大まかなグループわけの結果を左右するほどのも のではない。厳密には平板上にコロニーを形成させて 観察する必要があるが，この值は肉眼で見觉るコ口 ニ一を形成する時間，すなわち各菌株の FOR モデル の tr の值を近似的にグループ化したものと考えてよ い。個々の細菌株について $\operatorname{tr}$ の測定を行わなくても， $\operatorname{tr}$ の値を一定の幅で区切ってグループ分けするのに は，この方法で十分であろう。A グループのほとんど の菌株がパターン 1 でサンプル接種後に釣菌した時間 と同じ時間にコロニーを形成した。Bグループの菌株 も，パターン 1 が多かったが，パターン 2 が $18 \%$ 含ま れていた。Cグループはパターン 2 がパターン 1 を上 回り，Dグループではパターン $3 \cdot 4$ が他のグループよ り多く含まれていたが, パターン 1 も50\%近く認めら れた。

\section{考察}

肉眼で識別できるコロニーを形成するをでの時間が 異なる 4 グループの細菌群集を属構成でみた結果, 各 グループの属構成に大きな違いはなかった。各グルー プを構成している個々の細菌属には，早くコロニーを 形成する属や，遅くコロニーを形成する属があり (Table 1), 属によって一定しているよ5にも思われ た。早くコロニーを形成するのは, Pseudomonas, Aeromonas, Enterobacteriaceae, Moraxella, Staphylococcus といった属で，達く出現するのは Nocardia, Actinomycetales, Yeast, であった。しかし，属によっ て出現時間が決まっているものの割合は全体の半数以 下で，コロニーを形成する時間が様々である属，また 一定しない属が半数以上あり, 結果として 4 つのグ ループを属構成という点でみると差が認められなかっ たことになる。このことは, 属構成の多様性といら観 点からみるとより明らかで, 4 つのグループの中に優 占種となる属を持つるのはなく多様度指数の值は注 等しい。また，属構成の内容は 4 つのグループで異な るが,グループとしての特徵は認められなかった。

コロニー形成時間の異なる 4 グループの細菌群集の

が，何日目からスラント面で増殖が観察されたかを示 したのが Fig. 4 である。各グループの菌株数が異なる ので,グループ毎の全菌株に対する割合で示した。ス

属レベルでの種類構成に特徵的な差異が認められな かったのに対して，高分子化合物の分解能，糖類の発 酵性，および全活性は，早くコロニーを形成したAグ 


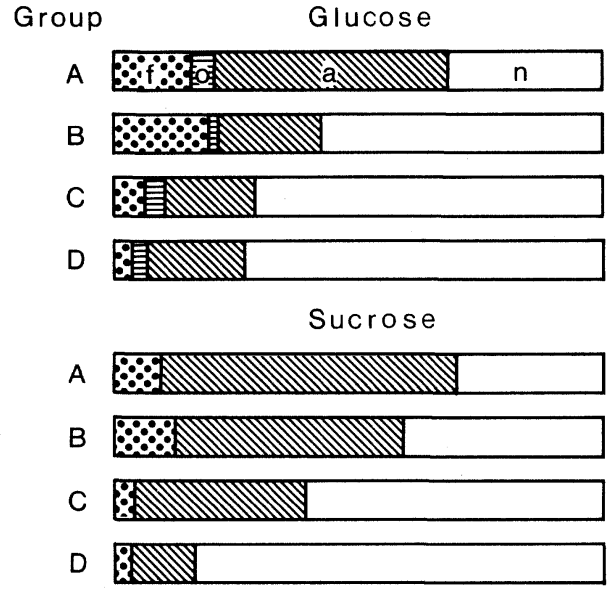

Raffinose

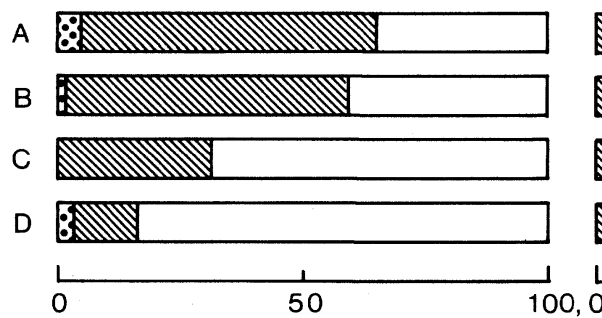

Fig. 3. OF-test reaction on the five carbohydrates of each bacterial group. Symbols were f; fermentation, o ; oxidation, a ; change to alkali, n; no color change was observed.

Table 2. Distributions of the specific total activity of four groups classified by colony forming time. Values correspond to the number of strains which have each specific total activity and the percentage show the ratio to the total strain number of each group.

\begin{tabular}{c|cccc}
\hline \multirow{2}{*}{$\begin{array}{c}\text { Total } \\
\text { activity }\end{array}$} & A & G & C & D \\
\cline { 2 - 5 } & $3(4.8 \%)$ & $3(5.8 \%)$ & 0 & 0 \\
\hline 11 & $5(8.1)$ & $4(7.7)$ & 0 & 0 \\
10 & $15(24.2)$ & $7(13.5)$ & $3(6.4 \%)$ & $3(9.1 \%)$ \\
9 & $10(16.1)$ & $8(15.4)$ & $2(4.3)$ & 0 \\
8 & $4(6.5)$ & $3(5.8)$ & $1(2.1)$ & $2(6.1)$ \\
7 & $3(4.8)$ & $3(5.8)$ & $7(14.9)$ & $2(6.1)$ \\
6 & $6(9.7)$ & $2(3.8)$ & $3(6.4)$ & 0 \\
5 & $7(11.3)$ & $9(17.3)$ & $6(12.8)$ & $1(3.1)$ \\
4 & $2(3.2)$ & $6(11.5)$ & $11(23.4)$ & $3(9.1)$ \\
3 & $3(4.8)$ & $2(3.8)$ & $6(12.8)$ & $10(30.3)$ \\
2 & $4(6.5)$ & $4(7.7)$ & $6(12.8)$ & $10(30.3)$ \\
1 & 0 & $1(1.9)$ & $2(4.3)$ & $2(6.1)$ \\
0 & 6.24 & 5.90 & 4.30 & 3.62 \\
\hline
\end{tabular}




\section{Group Pattern}

A

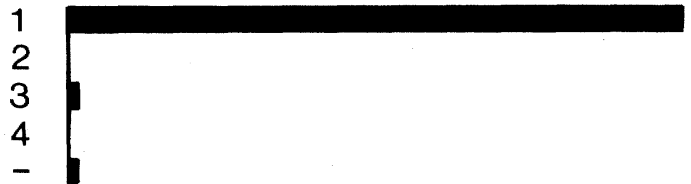

B

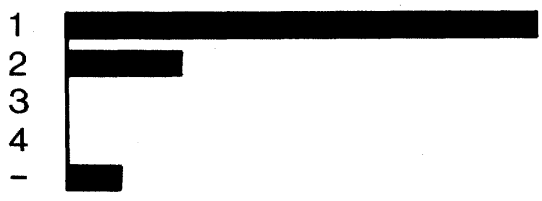

C

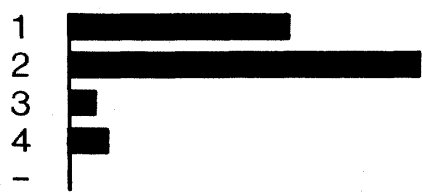

D

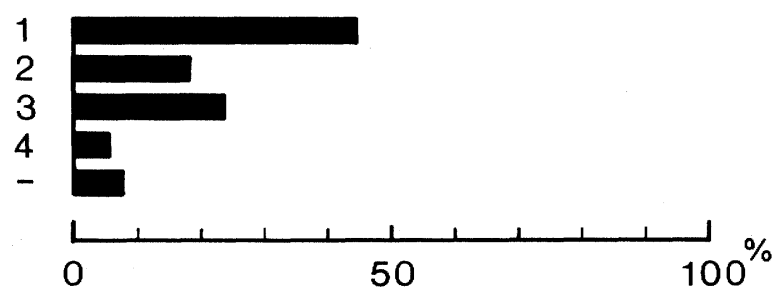

Fig. 4. Patterns of the colony developing time of each bacterial strain of the four groups inoculated to the $1 / 2$ PYG agar slants. Pattern 1,2,3, and 4 correspond to the strains which showed visible colonies at $48,72,168$, and 336 hours of incubation time, respectively. The values show the percentage of the number of the strains to total bacterial number of each group.

ループの菌株の方が王倒的に高く、ゆっくりとコロ ニーを形成した細菌株では低かった。

平板上にコロニーが形成されるまでの時間は，細菌 細胞が分裂を開始するまでの待ち時間と, コロニーと して目に見える大ささに増殖するまでの時間を加算し たものである。Fig. 2, Fig. 3 で明らかなよらに早くコ ロニーを形成するグループと，ゆっくりコロニーを形 成するグループでは有機物の分解能が大きく異なって 掞り，これは数種類の物質に対する反応が同じであっ たことから，早くコロニーを形成する菌株とゆっくり コロニーを形成する菌株の差は, 細菌細胞のエネル ギー源となる物質の分解能が高いかあるいは低いかの 差といらことになる。本報には詳述しなかったが，こ のことはスラントに接種した各細菌株の増殖量からも 明らかであった。スラントの接種面での菌体量の増え 方は AグループからDグループにいくにしたがって
減少し, 増殖量が小さい菌株の割合はAグループから Dグループにいくにしたがって多くなった。接種量は 等しいのに，A グループでは多くの細菌株で接種した スラント面に多量の菌株が認められたのに対して，D グループの菌株のスラント面には1つのコロニーが小 さく, 点在してみえるような増殖しか起こらなかった。 また，50日目にスラントに接種した菌株がスラント面 で肉眼でみえるようになる時期を比較すると（Fig 4), A グループはパターン 1 が圧倒的に多かったが，B グループでは遅いものが混じり，C・Dグループにいく にしたがって肉眼でみえるコロニーを形成する時間に ばらつきがみられるよらになった。増殖のパターンす なわちコロニーを形成し始める時間は，当初コロニー を釣菌した平板上でのコロニーの出現時間と同じく，

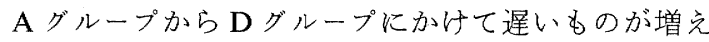
て招り，コロニー形成時間が遅い菌株は活性が低いと 
同時に, コロニー形成に要する時間, すなわち FOR モ デルの 1 つの係数 $\operatorname{tr}$ の值が長いということが明らか になった。このよらに, Aグループの菌株は D グルー プの菌株より有機物の分解能が高く, かつすばやくコ ロニーを形成する菌株であった。Bグループの菌株の コロニ一形成は, 釣菌時にはわずか 24 時間の違いで あったが, パターン 2 の菌株が $20 \%$ 混じり活性もやや 低くグループの構成が変わり，Cグループではさらに その傾向が強くなった。Dグループではパターン 3 が $30 \%$ 近く混じって抒り，グループとしてコロニー形成 時間がへテロな構成であったといえる。

服部1 は自然界の細菌群集によるコロニー形成曲線 はいくつかの成分曲線からなり, 平板上のコロニー形 成現象が母細胞集団の生理的状態に関する情報をも秘 めているとしている。清水ら》は, 平板上にコロニーを つくるまでの日数は細菌の種類によって比較的一定し て打り, 多くの細菌細胞は栄養濃度が低くなるとコロ ニーの出現が遅くなるだけでなくコロニーが現れるま での時間の幅が広くなると報告した。そして, 細菌群 集の中でコロニ一をつくる確率というものがもし存在 するとしても，それは培養基濃度等，細菌の沶かれて いる環境によって規定されるような相対的なるのであ ろうとした。本報で得られた結果は, 多摩川の河床付 着層の細菌群集をコロニー形成時間でみると, 出現時 期が決っているものがある反面, 半数以上は出現時間 が不定であり，早くコロニーを形成するグループは活 性が高いが，遅いグループはへテロな群集になってお り, 平板上に打けるコロニ一形成はその細菌株が持っ ている遺伝的な性質之, 細菌細胞が平板に沶かれた時 点での生理的な状態に基づいて決まる事を示唆してい る。A グループのような活性の高い細菌株はいつも早 くコロニーを形成するが，Dグループはコロニー形成 時間がパターン 1 からパターン 4 まで混じって拈り, 細菌細胞が平板に接種された時の生理的状態に基づい てコロニー形成が行われたのであろう。これらの細菌 株を再び混合した後平板に接種し，コロニー形成時間
の違いで分離したならば, A グループの細菌株は A グ ループとして釣菌されるであろらが，Dグループの細 菌株は異なるグループで釣菌される可能性がある。今 後検討される必要があろう。

な打本研究の一部は，とらきゅう環境浄化財団の助 成金によって行われた。ここに報告して感謝の意を表 する。

\section{引用文献}

1) 服部 勉. “徵生物学の基礎” 学会出版センター 1986. pp. 99-115.

2) Ishikuri, S., Y. Suwa, and T. Hattori. 1984. Method for mathematical analysis of bacterial count data. Soil Sci. Plant Nutr., 30, 249-253.

3) Krieg, N.R., and J.G. Holt. Bergey's Manual of Systematic Bacteriology. 1. Williams \& Wilkins, Baltimore, 1984.

4）森川和子。1984. 多摩川上流域における好気性従 属栄養細菌数の季節変動とそれの環境要因との関 係について. 陸水学雑誌 45: 69-78.

5) Morikawa, K. 1987. Characteristics of generic composition of aerobic heterotrophic bacteria in periphyton at an oligotrophic region in the Tamagawa River. Jpn. J. Limnol., 48 : 55-65.

6) Shannon, C.E., and W. Weaver. The Mathematical Theory of Communication. University of Illinois Press, Urbana, 1963, pp. 117.

7) 清水 潮, 塚本久美子, 木暮一啓. 1982. 寒天培 地平板上での海洋細菌の増殖. 大桘臨海研究セン ター報告 $8: 69-76$.

8) Sneath, P.H.A., N.S. Mair, M.E. Sharpe, and J.G. Holt. Bergey's Manual of Systematic Bacteriology. 2. Williams \& Wilkins, Baltimore, 1986.

9) 染谷 孝, 古坂澄石. 1981. 水田土壌の好気性七 ルロース分解菌——方法上の諸問題をめぐって 一. 土と微生物 23: 23-31.

10) Staley, J.T., M.P. Bryant, N. Pfenning, and J.G. Holt. Bergey's Manual of Systematic Bacteriology. 3. Williams \& Wilkins, Baltimore, 1989.

11) Williams, S.T., M.E. Sharpe, and J.G. Holt. Bergey's Manual of Systematic Bacteriology. 4. Williams \& Wilkins, Baltimore, 1989. 